\title{
Microbial enhancement of plant nutrient acquisition
}

\author{
Sunil K. Singh ${ }^{1}$, Xiaoxuan $\mathrm{Wu}^{1,2}$, Chuyang Shao ${ }^{1,2}$ and Huiming Zhang ${ }^{1 *}$ (D)
}

\begin{abstract}
Nutrient availability is a determining factor for crop yield and quality. While fertilization is a major approach for improving plant nutrition, its efficacy can be limited and the production and application of fertilizers frequently bring problems to the environment. A large number of soil microbes are capable of enhancing plant nutrient acquisition and thereby offer environmentally benign solutions to meet the requirements of plant nutrition. Herein we provide summations of how beneficial microbes enhance plant acquisition of macronutrients and micronutrients. We also review recent studies on nutrition-dependent plant-microbe interactions, which highlight the plant's initiative in establishing or deterring the plant-microbe association. By dissecting complex signaling interactions between microbes within the root microbiome, a greater understanding of microbe-enhanced plant nutrition under specific biotic and abiotic stresses will be possible.
\end{abstract}

Keywords: Beneficial microbes, Plant, Macronutrient, Micronutrient, Plant-microbe interactions, Volatile organic compounds, Microbiome

\section{Introduction}

In addition to the elements carbon $(\mathrm{C})$, hydrogen $(\mathrm{H})$, and oxygen $(\mathrm{O})$ that can be provide from $\mathrm{CO}_{2}$ and water, terrestrial plants commonly require a list of elemental nutrients from the soil to support healthy growth and development. These essential nutrients include nitrogen $(\mathrm{N})$, phosphorus $(\mathrm{P})$, potassium $(\mathrm{K})$, sulfur $(\mathrm{S})$, magnesium $(\mathrm{Mg})$, and calcium $(\mathrm{Ca})$, which are collectively termed macronutrients due to the relatively large quantities required for plants, as well as iron (Fe), manganese $(\mathrm{Mn})$, copper $(\mathrm{Cu})$, zinc $(\mathrm{Zn})$, boron $(\mathrm{B})$, molybdenum $(\mathrm{Mo})$, chlorine $(\mathrm{Cl})$, and nickel $(\mathrm{Ni})$, which are collectively termed micronutrients due to the relatively small plant requirement. Plant deficiency in each of the macronutrients and micronutrients leads to varying consequences at molecular and phenotypic levels (Andresen et al. 2018, Gong et al. 2020).

Deficiency of one or more nutrients available for plant utilization is common in natural soils. For

\footnotetext{
* Correspondence: hmzhang@psc.ac.cn

${ }^{1}$ Shanghai Center for Plant Stress Biology, Center for Excellence in Molecular Plant Sciences, Chinese Academy of Sciences, Shanghai 201602, China Full list of author information is available at the end of the article
}

example, only a very small fraction of $\mathrm{P}$ in soils and bedrocks is potentially available to plants (Alewell et al. 2020), meanwhile nearly $50 \%$ of the ricegrowing soils are Zn-deficient (Krithika and Balachandar 2016). Fertilization is a major approach for improving plant nutrition. However, the efficacy of fertilization in agriculture can be limited by environmental interferences, as exemplified by $\mathrm{Zn}$ fertilization with the water soluble zinc sulfate, which is often precipitated as hydroxides, carbonates, phosphates and sulfides in the soil and consequently shows only 1-5\% fertilizer use efficiency (Krithika and Balachandar 2016). More importantly, the production and application of fertilizers in global agriculture have posed serious problems to the environment. For instance, industrial production of $\mathrm{N}$ fertilizers consumes 1-2\% of the world's fossil fuel energy output (Chen et al. 2018), meanwhile plants take up only $30-50 \%$ of $\mathrm{N}$ available in the soil and the remaining $\mathrm{N}$ fertilizers are lost through nitrification or denitrification processes, which cause eutrophication and other hazardous impacts to soil, water, and the atmosphere (Lehnert et al. 2018). Similarly, the agricultural usage 
of industrial P fertilizer has been not only increasingly consuming non-renewable geological $\mathrm{P}$ deposits, but also making major contributions to the eutrophication of fresh and costal water bodies around the world (Smil 2000, Alewell et al. 2020).

Plants naturally live with a plethora of soil microbes, some of which are beneficial in that they can promote plant growth and/or increase plant resistance to one or multiple stress conditions, including nutrient deficiency (Kloepper et al. 1980, Lugtenberg and Kamilova 2009; Morcillo and Manzanera, 2021). Within the rhizosphere where root exudates provide an environment enriched with organic nutrients, beneficial microbes can be free-living or directly associated with plants as epiphytes or endophytes; particularly, plant-associated fungi extend mycelia to additional soil beyond the rhizosphere and can therefore reach for more nutrients to support the association (Fig. 1). These beneficial microbes provide an environment-friendly approach for improving plant nutrition, either as enhancers or alternatives to chemical fertilizers. Some of the beneficial microbes, such as rhizobia that fix atmospheric nitrogen, are well-known and have been applied in agriculture, while many others remain to be characterized and exploited. Herein we review how beneficial microbes improve plant acquisition of the macronutrients $\mathrm{N}, \mathrm{P}, \mathrm{K}, \mathrm{Mg}$, and $\mathrm{S}$ as well as the micronutrients $\mathrm{Fe}, \mathrm{Mn}, \mathrm{Cu}, \mathrm{Zn}, \mathrm{B}, \mathrm{Mo}$, and $\mathrm{Ni}$. We also review recent works that investigated nutritiondependent plant-microbe interactions, which demonstrate the plant's initiative in determining the plant-microbe association for optimized benefits including P nutrition.

\section{Microbial enhancement of plant macronutrient acquisition}

Nitrogen ( $\mathrm{N}$ )

Microbes play significant roles in plant acquisition of ammonium $\left(\mathrm{NH}_{4}^{+}\right)$and nitrate $\left(\mathrm{NO}_{3}{ }^{-}\right)$. Diazotrophs are $\mathrm{N}_{2}$-fixing bacteria and archea with nitrogenase that catalyzes the reduction of atomospheric $\mathrm{N}_{2}$ to $\mathrm{NH}_{3}$, which is then ionized to $\mathrm{NH}_{4}{ }^{+}$favoring low environmental $\mathrm{pH}$. Ammonium is also generated by bacterial or fungal decomposition of organic debris and can be oxidized by nitrifying bacteria to nitric oxides and nitrates. Some $\mathrm{N}_{2}$-fixing bacteria are free-living in soil, while others are plant-associated or even require symbiosis with plants to fix $\mathrm{N}_{2}$ (Fig. 1a). Symbiotic $\mathrm{N}_{2}$ fixation occurs in root nodules, where the specialized environment ensures the bacterial fixation of $\mathrm{N}_{2}$ and the bacteroids receive plantderived organic nutrients in exchange of $\mathrm{NH}_{3}$ (Mus et al. 2016, Roy et al. 2020). Plants capable of forming nodules mostly belong to the family of Leguminosae.

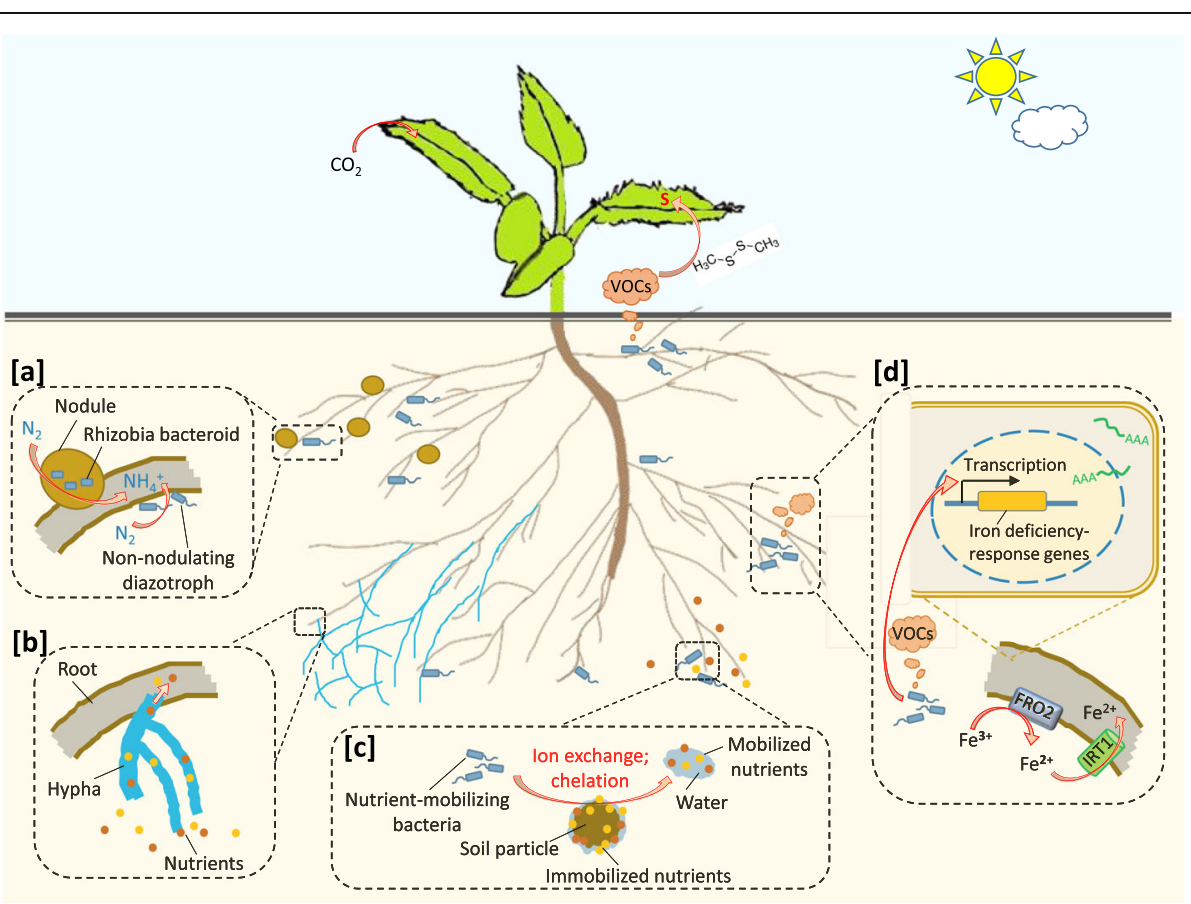

Fig. 1 Microbe-enhanced plant acquisition of macronutrients and micronutrients. Beneficial microbes enhance plant nutrient acquisition via multiple mechanisms, including but not limited to [a] $\mathrm{N}_{2}$ fixation by rhizobia in nodules or by non-nodulating diazotrophs; [b] Nutrient uptake and delivery through mycorrhizal mycelia that reaches additional soil beyond the root; [c] Mobilization of soil-fixed nutrients through ion exchange or chelation by bacterial or fungal secretions, such as organic acids and siderophores; [d] Microbe-induced transcriptional regulation of plant genes involved in nutrient uptake, such as Arabidopsis Fe deficiency responses that are induced by bacteria volatile organic compounds (VOCs). Microbes may also enhance plant S nutrition via certain S-containing VOCS, such as dimethyl disulfite, which can be assimilated by the aerial portion of plants 
These leguminous plants host species-specific symbiosis with rhizobia from the Rhizobiaceae family (Andrews and Andrews 2017). In addition to rhizobia-legume symbiosis, $\mathrm{N}_{2}$-fixing nodulation also occur in Parasponia species that host rhizobia and in actinorhizal plants that host the actinomycete Frankia (Svistoonoff et al. 2014, van Velzen et al. 2018).

Plant $\mathrm{N}$ acquisition can also be improved by nonnodulating diazotrophs. For instance, inoculation with the nitrogen-fixing cyanobacterium Nostoc punctiforme resulted in detectable nitrogenase activity in rice roots and promotion of plant growth under nitrogen deficiency (Álvarez et al. 2020). Azospirillum brasilense strain HM053, which fixes nitrogen and excretes $\mathrm{NH}_{4}{ }^{+}$ constitutively, was capable of colonizing the surface of wheat roots and substantially increasing the plant dry weight (Santos et al. 2017). In addition, horizontal transfer of the nitrogen fixation (nif) genes can enable the capacity of nitrogen fixation in non-diazotrophic microbes (Dixon and Postgate 1971, Jing et al. 2020). For instance, genetic engineering of the nif genes from a Pseudomonas stutzeri strain into a Pseudomonas protegens strain enables the latter the ability of nitrogen fixation and consequently causing plant growth-promotion under nitrogen deficiency (Jing et al. 2020).

Besides diazotrophs, mycorrhizal fungi are also wellknown to improve plant $\mathrm{N}$ acquisition, because mycorrhizal mycelia reaches additional soil beyond the root for more nutrients and can transport the assimilated $\mathrm{N}$ to the roots in a mutualistic relation (Fig. 1b). By using stable isotope labelling of $\mathrm{N}$, it has been shown that inorganic nitrogen taken up by arbuscular mycorrhizal (AM) fungus outside the roots is incorporated into amino acids, translocated from the extraradical to the intraradical mycelium as arginine and transferred to the plant without carbon (Govindarajulu et al. 2005). In addition, plant transporters for $\mathrm{N}$ acquisition can be upregulated by fungal symbionts. For instance, colonization of the AM fungus Rhizophagus irregularis strongly induced gene expression of the putative nitrate transporter OsNPF4.5 in rice roots and promoted plant growth with remarkable increases in $\mathrm{N}$ acquisition, whereas knockout of OsNPF4.5 resulted in a $45 \%$ decrease in symbiotic $\mathrm{N}$ uptake and a significant reduction in arbuscule incidence when $\mathrm{NO}_{3}{ }^{-}$was supplied as an $\mathrm{N}$ source (Wang et al. 2020). Given that most staple crops are non-legumes, these non-nodulating bacteria and fungi offer important tools for improving plant $\mathrm{N}$ nutrition in agriculture.

\section{Phosphorus (P)}

The majority of natural $\mathrm{P}$ in soil are in insoluble form and thus unavailable to plants (Richardson and Simpson 2011). A wide variety of bacteria and fungi species are capable of solubilizing inorganic $\mathrm{P}$ and/or mineralizing organic $\mathrm{P}$, thereby releasing bioavailable $\mathrm{P}$ that can be readily absorbed by plants (Fig. $1 \mathrm{~b}, \mathrm{c})$. Strains from the bacteria genera Pseudomonas, Bacillus and Rhizobium are among the most powerful P-solubilizing microbes (Rodríguez and Fraga 1999). Immobilized inorganic P can be released by microbe-secreted organic acids, such as gluconic acid and citric acid. Anions from these organic acids chelate cations that otherwise precipitate P-containing anions (Whitelaw et al. 1999), meanwhile acidification of the soil environment releases $P$ from precipitates through the formation of soluble hydrogen $\left(\mathrm{HPO}_{4}{ }^{2-}\right)$ or dihydrogen $\left(\mathrm{H}_{2} \mathrm{PO}_{4}{ }^{-}\right)$phosphates (Sharma et al. 2013). Protons that causes acidification can also be secreted through $\mathrm{H}^{+}$-ATPase, through transporterassisted cation exchange across the microbial membranes, or in the form of inorganic acids (Alori et al. 2017). Microbial mineralization of organic P is mainly catalyzed by non-specific acid phosphatases that dephosphorylate the phosphor-ester or phosphoanhydride bonds of organic molecules (Nannipieri et al. 2011), as well as by phytases that specifically hydrolyze phytate (myo-inositol hexakisphosphate) in releasing the orthophosphate anion (Mitchell et al. 1997, Lim et al. 2007). The hydrolysis of phytate by phytases produces myo-inositol (Mitchell et al. 1997), which is a common component of root exudates in many plant species (Vílchez et al. 2020). Phytate is the most abundant organic phosphorus compound in soil (Lim et al. 2007), while myo-inositol attracts Bacillus megaterium spp. that is well-known for strong P-solubilizing ability (Vílchez et al. 2020). Thus it is an interesting question whether the plant exudation of myo-inositol carries a function in attracting B. megaterium spp. for bacteria-assisted $\mathrm{P}$ acquisition from the hydrolysis of phytate.

In addition to providing more bioavailable P to plants, beneficial microbes can also stimulate plant $\mathrm{P}$ uptake through regulation of plant $\mathrm{P}$ transporters. For instance, colonization of AM fungi significantly increased the transcript level of LePT4, a phosphate transporter in tomato plants, with a concomitant 2 -fold increase in phosphate uptake; meanwhile a loss-of-function mutation in LePT4 significantly impaired the AM fungienhanced phosphate uptake (Xu et al. 2007). LePT4 belongs to the Pht1 family of plant phosphate transporters, which are expressed at both the root-soil interface and the symbiotic fungus-plant interface around arbuscules or hyphal coil (Nagy et al. 2005). Phosphate transporter genes specifically activated in AM fungi symbiosis have been identified in many agricultural plant species, such as potato (Solanum tuberosum), rice (Oryza sativa), and Medicago truncatula (Rausch et al. 2001, Harrison et al. 2002, Paszkowski et al. 2002).

Fungi may be considered as more effective tools than bacteria in promoting plant $\mathrm{P}$ acquisition, because the 
former release more organic acids, reach more resources, and are capable of transmitting phosphate to the symbiotic plant cells (Sharma et al. 2013). However, a combination of P-solubilizing bacteria and fungi can result in better effects than bacteria or fungi alone. For instance, a combinational inoculation with AM fungi and beneficial rhizobacteria to durum wheat increased transcript levels of the P transporters Pht1 and PT2-1 as well as the aboveground $\mathrm{P}$ contents; in contrast, AM fungi alone induced Pht2 gene expression and required additional supply of organic $\mathrm{N}$ to similarly increase plant $\mathrm{P}$ contents (Saia et al. 2015). Recently it was shown that the extraradical hyphae of AM fungi can transport Psolubilizing bacteria to organic $\mathrm{P}$ patches and enhance organic $\mathrm{P}$ mineralization both under in vitro culture and soil conditions, in a way that hyphal exudates are required as the energy source for transferring the bacteria (Jiang et al. 2021), thus supporting the advantage of using fungi and bacteria in combinations for enhancing $\mathrm{P}$ acquisition in plants.

\section{Potassium (K)}

In most soils, the solution and exchangeable $\mathrm{K}$ constitute only a few percent of the total soil K (Brady et al. 2008). Many bacterial and fungal strains have been documented as capable of releasing $\mathrm{K}$ from silicate minerals such as mica, biotite, and orthoclase (Meena et al. 2014, Masood and Bano 2016). These microbes enhance mineral weathering under in vitro conditions and increase $\mathrm{K}$ solubilization in soil, mainly through acidolysis, chelation and exchange reactions, in which microbe-secreted organic acids play an important role (Masood and Bano 2016, Meena et al. 2014). K enrichment resulted from AM fungi colonization has been demonstrated in different plant organs such as Zea mays root steles, Pelargonium peltatum shoots, and Lactuca sativa leaves (Perner et al. 2007, Baslam et al. 2013).

Many of the K-solubilizing microbes are saprophytic strains (Meena et al. 2014). Colonization by Clitopilus hobsonii, a common soil saprophytic fungus, increased plant growth and facilitated $\mathrm{K}$ uptake in the American sweetgum (Liquidambar styraciflua), particularly under $\mathrm{K}$ limitation conditions (Peng et al. 2021). Gene expression of ChACU, a putative $\mathrm{K}^{+}$transporter in C. hobsonii, were detected in the colonized roots together with two other similar genes and were up-regulated by low $\mathrm{K}^{+}$ conditions; however, the expression of plant genes related to $\mathrm{K}^{+}$uptake was not altered by the symbiosis with C. hobsonii (Peng et al. 2021). Thus the C. hobsonii $\mathrm{K}^{+}$ transporters appear to play a more active role than the sweetgum $\mathrm{K}^{+}$transporters in the symbiotic supply of $\mathrm{K}$. In contrast, fungal induction of plant putative $\mathrm{K}^{+}$transporter genes was observed in perennial ryegrass (Lolium perenne) colonized by Aspergillus aculeatus, concomitant with higher levels of soluble $\mathrm{K}$ contents ( $\mathrm{Li}$ et al. 2021). In another symbiosis example, the ectomycorrhizal fungus Hebeloma cylindrosporum significantly improved the K nutrition of pine (Pinus pinaster) plants under potassium-limiting conditions, and the fungal tandem-pore outward-rectifying $\mathrm{K}^{+}$(TOK) channels are likely responsible for releasing $\mathrm{K}^{+}$from the fungal Hartig net to the plant (Guerrero-Galán et al. 2018). The efficacy of microbial enhancement of plant $\mathrm{K}$ nutrition can be improved by co-application with K-containing minerals, as shown in perennial ryegrass treated with $\mathrm{A}$. aculeatus plus K-containing feldspar compared with plants treated with the fungus alone (Li et al. 2021).

\section{Sulfur (S)}

Plant sulfur nutrition depends primarily on the uptake of inorganic sulfate $\left(\mathrm{SO}_{4}{ }^{2-}\right)$, whereas more than $95 \%$ of the soil sulfur in agricultural soils is present as sulfate esters or as carbon-bonded sulfur in the forms of sulfonates and amino acid sulfur (Kertesz and Mirleau 2004, Zhao et al. 2006). Many bacterial and fungal species in the rhizosphere are capable of releasing $S$ from sulfate esters, as a result of the mineralization catalyzed by sulfatases, which include arylsulfatase that cleaves the O-S bond in aromatic sulfate-esters and alkylsulfatase that cleaves the $\mathrm{C}-\mathrm{O}$ bond in aliphatic sulfate-esters (Kertesz 2000). In contrast to the mineralization of sulfate esters, releasing $\mathrm{S}$ from sulfonates is catalyzed by a multicomponent mono-oxygenase enzyme complex encoded in the ssu gene cluster (Eichhorn et al. 1999), which is found in bacteria but not fungi (Gahan and Schmalenberger 2015). The ability of releasing $S$ from aliphatic sulfonates is widespread in soil bacteria (King and Quinn 1997), whereas releasing $S$ from aromatic sulfonates requires the asfRABC gene cluster in addition to the ssu gene cluster (Vermeij et al. 1999). Aliphatic and aromatic sulfonates together account for $30-70 \%$ soil S (Zhao et al. 2006). It was suggested that aromatic sulfonates are more important than aliphatic sulfonates in microbe-assisted plant $S$ nutrition, because bacterial ability in utilizing the former but not the latter has been associated with plant growth-promotion (Kertesz and Mirleau 2004, Gahan and Schmalenberger 2015). Although fungi are unable to mineralize sulfonates, some saprotrophic fungi may facilitate bacterial mineralization of sulfonates through depolymerizing polymeric sulfonates into monomeric or oligomeric sulfonates (Gahan and Schmalenberger 2015, Kertesz et al. 2007).

In addition to increasing the $\mathrm{SO}_{4}{ }^{2-}$ supply, soil microbes can also enhance plant $\mathrm{S}$ nutrition through transcriptional regulation of plant sulfate assimilation pathway. In Arabidopsis thaliana exposed to the volatiles organic compounds (VOCs) released from Bacillus 
amyloliquefaciens GB03, transcript levels of several genes, such as ATP sulfurlyase (ATPS) and adenosine 5' -phosphosulfate reductase (APR), in the sulfate assimilation pathway were up-regulated; concomitantly, VOC-enhanced plant sulfate uptake was observed with radio-labeled sulfate within $30 \mathrm{~min}$ (Aziz et al. 2016). In Lotus japonicas colonized by the AM fungus $R$. irregularis, gene expression of the sulfate transporter LjSultr1; 2 was localized in arbuscule-containing cells and upregulated by either the fungal colonization or $\mathrm{S}$ starvation (Giovannetti et al. 2014). Dysfunction of LjSultr1;2 decreased plant constitutive $S$ uptake, while the fungal colonization increased plant sulfate contents under $\mathrm{S}$ starvation (Giovannetti et al. 2014), thus supporting the importance of transcriptional regulation in the microbeassisted plant $\mathrm{S}$ nutrition.

Unlike other microbes that enhance plant $\mathrm{S}$ uptake in roots, Bacillus sp. B55 is capable of increasing plant sulfur acquisition in the air (Meldau et al. 2013). With radio-labeled sulfur ${ }^{35} \mathrm{~S}$ supplemented into the bacteria growth medium, B55 VOCs was shown to transmit sulfur to Nicotiana attenuata plants, which were grown in medium physically separated from the bacteria growth medium, and rescued plant growth retardation caused by sulfur starvation. Dimethyl disulfide (DMDS) was identified as the major S-containing component in B55 VOCs and responsible for the VOC-enhanced plant $\mathrm{S}$ nutrition (Meldau et al. 2013). Sulfur in $\mathrm{SO}_{4}{ }^{2-}$ is in an oxidative state that needs an energy-consuming reduction process for biological assimilation (Takahashi et al. 2011), whereas sulfur in DMDS is in a chemically reduced state, which may credit DMDS as an energysaving form of sulfur nutrition to plants. Consistent with this hypothesis, sulfur assimilation as well as methionine biosynthesis and recycling in plants were transcriptionally repressed by DMDS, indicating a decreased demand for $\mathrm{SO}_{4}{ }^{2-}$ reduction (Meldau et al. 2013). DMDS is a common component in microbial VOCs; meanwhile other microbes can produce VOCs with high levels of other sulfur-containing compounds such as dimethyl sulfide and dimethyl trisulfide (Kanchiswamy et al. 2015). Therefore, VOC-mediated sulfur assimilation in the air might be a common mechanism for microbeenhanced plant $\mathrm{S}$ nutrition.

\section{Magnesium (Mg)}

Plants grown in acidic and sandy soils frequently suffer from $\mathrm{Mg}$ deficiency due to leaching and antagonism by other cations (Hermans et al. 2010). A few examples have been reported for microbe-mediated alleviation of plant $\mathrm{Mg}$ deficiency. In $A$. thaliana particularly under $\mathrm{Mg}$ deficiency condition, the plant $\mathrm{Mg}$ nutrition was improved by the colonization of Piriformospora indica, a root endophytic fungus that possesses the $\mathrm{Mg}$ transporter PiMgT1 (Prasad et al. 2019). Inoculation of AM fungus Funneliformis mosseae to Poncirus trifoliata seedlings resulted in enhanced growth promotion and suppression of $\mathrm{Mg}$ deficiency symptoms; the reduction in $\mathrm{Mg}$ deficiency symptoms may be attributed to the fungus-induced elevations in whole-plant soluble protein levels and in the activity of root catalase and superoxide dismutase (Zhang et al. 2015). Interesting, the colonization of $F$. mosseae to $P$. trifoliata roots was significantly higher under Mg-deficiency than under Mg-sufficiency (Zhang et al. 2015), whereas sweet potato and onion leaves sprayed with high levels of $\mathrm{MgSO}_{4}$ displayed strongly inhibited root AM fungus colonization and sporulation in aeroponic and sand culture (Jarstfer et al. 1998), indicating a negative correlation between plant $\mathrm{Mg}$ availability and AM fungi colonization to roots.

\section{Microbial enhancement of plant micronutrient acquisition \\ Iron (Fe)}

Plants use different strategies to increase iron mobility in the rhizosphere. Graminaceous monocots secret siderophores to chelate ferric iron $\left(\mathrm{Fe}^{3+}\right)$ before its root uptake, while non-graminaceous monocots and dicots deploy a combined strategy including rhizosphere acidification, reduction of $\mathrm{Fe}^{3+}$ to ferrous iron $\left(\mathrm{Fe}^{2+}\right)$ by plasma membrane ferric reductase, and transportermediated $\mathrm{Fe}^{2+}$ import into roots (Curie and Briat 2003). These strategies are involved in microbial enhancement of plant iron acquisition (Fig. 1d).

Microbial siderophores in their Fe-bound forms can be directly absorbed by plants. Hydroxymates and catechols are the major functional groups in the ironsiderophore binding (Rajkumar et al. 2010). Siderophores produced from different microbes can be characterized by their structural differences, for instance, siderophores in the form of rhizobactin (catechol-containing) and citrate (neither a catechol nor a hydroxamate) are released from Rhizobium meliloti and Bradyrhizobium japonicum, respectively (Smith et al. 1985, Guerinot et al. 1990). In addition to providing microbial siderophores, certain microbes also stimulate plant production of phytosiderophores. In sorghum (Sorghum bicolor) under Fe deficiency, gene expression of SbDMAS2 (deoxymugineic acid synthase 2), SbNAS2 (nicotianamine synthase 2), and SbYS1 (Fe-phytosiderophore transporter yellow stripe) was induced by AM fungus, concomitant with significant increases in phytosiderophore release and Fe uptake in the plant (Prity et al. 2020).

Acidification improves $\mathrm{Fe}^{3+}$ mobility, thus, rhizosphere acidification stimulated or directly contributed by $\mathrm{mi}$ crobes facilitates plant iron acquisition. Organic acids commonly exist in microbial extracellular metabolites. For instance, the VOCs from B. amyloliquefaciens GB03 
contain glyoxylic acid, 3-methyl-butanoic acid and diethyl acetic acid (Farag et al. 2006), which directly causes rhizosphere acidification (Zhang et al. 2009). GB03 VOCs also stimulate plant acidification of the rhizosphere, as shown by VOC-exposed Arabidopsis that were transferred to new growth medium with no VOCs anymore (Zhang et al. 2009). Importantly, Arabidopsis under Fe-sufficient conditions responded to GB03 VOCs with systemic Fe-deficiency responses, including transcriptional induction of the $\mathrm{Fe}^{3+}$ reductase $\mathrm{FRO} 2$ and the $\mathrm{Fe}^{2+}$ transporter IRT1, as well as elevated enzyme activity of FRO2, in addition to the stimulation of rhizosphere acidification by the plant (Zhang et al. 2009). As a result, Fe levels were elevated in the VOC-exposed plants (Zhang et al. 2009), in supporting plant production of greater amounts of $\mathrm{Fe}$-containing photosynthetic apparatus (Zhang et al. 2009, Zhang et al. 2008). The phenotype and/or mechanism of GB03 VOC-enhanced plant Fe acquisition were similarly observed in many later studies, including investigations on other plants species, VOCs from other microbes, and soil inoculation with GB03 or other beneficial microbes (del Carmen Orozco-Mosqueda et al. 2013a, del Carmen OrozcoMosqueda et al. 2013b, Castulo-Rubio et al. 2015, Freitas et al. 2015, Zamioudis et al. 2015, Zhou et al. 2016, Martínez-Medina et al. 2017, Hernández-Calderón et al. 2018, Montejano-Ramírez et al. 2020, Kong et al. 2021). Therefore, microbial regulation of plant Fe-deficiency responses plays a prominent role in microbe-enhanced plant Fe acquisition (Fig. 1d).

The volatile compound $N, N$-dimethylhexadecylamine (DMHDA), which is commonly produced by several bacteria strains belonging to Arthrobacter agilis, Sinorhizobium meliloti, or Pseudomonas fluorescens, was shown to induce plant Fe-deficiency responses (del Carmen Orozco-Mosqueda et al. 2013a, Castulo-Rubio et al. 2015, Montejano-Ramírez et al. 2020). GB03 VOCs' effects on plant Fe-acquisition requires transcriptional induction of FIT1 (Zhang et al. 2009), a master regulator of Fe-deficiency responses conserved in plants (Riaz and Guerinot 2021). The bioactive VOC component(s) responsible for this key regulatory step along with its mechanism have been elusive. Although identifying the bioactive component or combination from natural microbial VOC blends has been challenging, the beneficial effects of microbial VOCs on plant resistance to biotic and abiotic stress have been accumulating (Farag et al. 2013, Liu and Zhang 2015, Weisskopf et al. 2021), making these microbial metabolites important resources for developing new tools for agricultural applications.

\section{Copper (Cu)}

AM fungi are capable of increasing plant fitness under $\mathrm{Cu}$ deficient and toxic conditions (Ferrol et al. 2016). In white clover (Trifolium repens L.) plants colonized by Glomus mosseae, the improvement in plant $\mathrm{Cu}$ nutrition was attributed to extraradical mycelia that extend out of the root into the surrounding environment for more nutrients (Li et al. 1991). Similarly, G. mosseae colonization increased $\mathrm{Cu}$ contents in the shoots of cucumber (Cucumis sativus), owing to extraradical myceliadependent nutrient uptake (Lee and George 2005). In the mycorrhizalwhite clover, the fungal contribution to plant $\mathrm{Cu}$ uptake was independent of $\mathrm{P}$ availability; however, increases in exogenous $\mathrm{P}$ supplies from soil changed the distribution patterns of the $\mathrm{Cu}$ contents contributed by G. mosseae, with a decrease and an increase in the roots and the shoots, respectively ( $\mathrm{Li}$ et al. 1991). Similarly, in the mycorrhizal cucumber plants, high levels of $\mathrm{P}$ supply to hyphae resulted in decreased root $\mathrm{Cu}$ concentrations (Lee and George 2005), thus drawing attentions to the crosstalk among different nutrient improvements in mycorrhizal plants.

Bacterial improvements of plant $\mathrm{Cu}$ nutrition have been correlated with microbial siderophores or modulation of certain plant genes. In alfalfa (Medicago sativa) seedlings, the $\mathrm{Cu}$ and Fe uptake was enhanced by two siderophores producing bacteria strains of $P$. fluorescens and Rhizobium leguminosarum bv phaseoli (CarrilloCastañeda et al. 2002). In cucumber plants under $\mathrm{Cu}$ deficiency or dual deficiency of $\mathrm{Cu}$ and $\mathrm{Fe}$, plant stress symptoms were alleviated by the plant-beneficial bacteria A. brasilense, accompanied by better root development and nutrient uptake (Marastoni et al. 2019). In consistence with the bacteria-enhanced plant nutrient uptake, $A$. brasilense-induced CsFRO gene expression was observed in the cucumber plants, which take up $\mathrm{Cu}$ after FRO-mediated reduction (Marastoni et al. 2019).

\section{Manganese $(\mathrm{Mn})$}

Plants acquire Mn only in its divalent form $\left(\mathrm{Mn}^{2+}\right)$. Mn is poorly available for plant uptake in well-aerated calcareous soils, because alkaline and oxidative conditions favor the formation of water-insoluble Mn oxides; meanwhile $\mathrm{Mn}^{2+}$ soil dressing is rather ineffective to alleviate deficiency due to rapid oxidation of $\mathrm{Mn}^{2+}$ (Andresen et al. 2018). Since Mn availability in soils is determined by $\mathrm{pH}$, microbe-mediated rhizosphere acidification would improve plant Mn acquisition. Examples of bacterial mobilization of $\mathrm{Mn}$ can be seen in some acidophilic bacteria strains, such as Acinetobacter sp. and Lysinibacillus sp., which were used for Mn bioleaching from ores or mining waste water (Sanket et al. 2017, Ghosh et al. 2018). Similarly, Mn solubilizing fungal strains, such as Aspergillus terreus and Penicillium daleae, have been isolated from low-grade Mn mine tailings, and their Mn solubilizing ability was attributed to the mycelia production of organic acids such as oxalic 
acid, citric acid, maleic acid and gluconic acid (Mohanty et al. 2017).

Due to its low selectivity, the $\mathrm{Fe}^{2+}$ importer IRT1 is also one of the Mn transporter in plants (Barberon et al. 2014). In addition, the availability of both Fe and Mn in soil are determined by $\mathrm{pH}$ and redox potential. Thus, plant Mn uptake may be enhanced by microbes that are capable of triggering plant iron deficiency responses. In a calcareous soil, the rhizosphere microbiome of maize (Z. mays) harbored populations of $\mathrm{Fe}^{3+}$-reducing microbes and $\mathrm{Mn}^{4+}$-reducing microbes, with the latter being one magnitude greater than the former (Kothari et al. 1991). Consistent with this $\mathrm{Mn}^{4+}$-reducing potential, plants grown in natural soil accumulated higher levels of Mn than plants grown in sterilized soil. Interestingly, adding the AM fungus G. mosseae to the nonsterilized soil almost depleted the populations of $\mathrm{Mn}^{4+}$ reducing microbes and $\mathrm{Fe}^{3+}$-reducing microbes, while the rest of the total microbial population remained basically unchanged in terms of quantity; concomitantly, the native microbiome-dependent enhancement of plant $\mathrm{Mn}$ accumulation was substantially decreased by the fungus, although the mycorrhizal plants still showed mild increases in plant Mn levels, which likely resulted from the fungus-assisted uptake (Kothari et al. 1991). These observations demonstrated the ability of rhizosphere microbiome in enhancing plant $\mathrm{Mn}$ acquisition. In addition, the impacts of G. mosseae on the $\mathrm{Mn}^{4+}$-reducing and $\mathrm{Fe}^{3+}$-reducing microbes highlight the importance of considerations on native microbiome when applying microbes for plant benefits.

When applying microbes capable of enhancing $\mathrm{Mn}$ availability to plants, cautions are required since $\mathrm{Mn}$ in excess imposes ionic stress to plant cells. For instance, in soybean (Glycine max L.) with abundant soil $\mathrm{Mn}$ availability, inoculation with the AM fungus Glomus macrocarpum resulted in strong Mn accumulation, Mn toxicity symptoms and reduced biomass in comparison to control plants (Nogueira and Cardoso 2003). Although G. macrocarpum enhanced plant growth under low $\mathrm{Mn}$ availability conditions, the mycorrhizal plants showed lower Mn contents in both shoots and roots compared to the control plants, meanwhile the $\mathrm{P}$ contents in the mycorrhizal plants were increased (Nogueira and Cardoso 2003). In contrast to G. macrocarpum, two G. etunicatum and G. intraradices strains promoted plant growth with elevated plant $\mathrm{P}$ contents under both low and high soil $\mathrm{Mn}$ availability, even though mild increases in $\mathrm{Mn}$ contents occurred in the mycorrhizal plants with high Mn availability (Nogueira and Cardoso 2003). Therefore, evaluations on microbial efficacy in increasing plant $\mathrm{Mn}$ acquisition would help choose an optimized strain for broad-ranging usages.

\section{Zinc (Zn)}

Zn deficiency frequently impairs the yield and quality of staple food crops. It was estimated that about $50 \%$ of the rice-growing soils are under $\mathrm{Zn}$-deficient, and that $\mathrm{Zn}$ fertilization by using the soluble $\mathrm{ZnSO}_{4}$ typically result with very low fertilizer use efficiency (1-5\%) due to $\mathrm{Zn}$ immobilization in the soil (Krithika and Balachandar 2016). Zn-mobilizing microbes offer alternative tools for enhancing plant $\mathrm{Zn}$ acquisition. In rice (O. sativa) seedlings, comparable effects on plant $\mathrm{Zn}$ accumulation were observed between the $\mathrm{ZnSO}_{4}$ fertilization and the application of insoluble $\mathrm{Zn}$ oxide bound with $\mathrm{Zn}$-mobilizing bacteria (Krithika and Balachandar 2016). In another experiment with natural soil deficient in $\mathrm{Zn}$, application of $\mathrm{Zn}$-mobilizing bacteria resulted in better effects in increasing plant $\mathrm{Zn}$ contents than $\mathrm{Zn}$ fertilization at the rate of $2.5 \mathrm{mg} \mathrm{Zn}$ as $\mathrm{ZnSO}_{4} .7 \mathrm{H}_{2} \mathrm{O}$ per $\mathrm{kg}$ soil (Vaid et al. 2014). A variety of bacteria such as Pseudomonas and Bacillus strains are known to enhance plant growth with higher $\mathrm{Zn}$ contents, and the microbial mobilization of $\mathrm{Zn}$ were attributed to different mechanisms mediated through rhizosphere acidification, sequestration by siderophores or anions from organic acids, and oxidoreductive systems on cell membranes (Kamran et al. 2017). Fungi-assisted plant $\mathrm{Zn}$ acquisition is also evident. In mycorrhizal bread wheat (Triticum aestivum) and barley (Hordeum vulgare), the fungal contribution of plant $\mathrm{Zn}$ uptake was measured as up to $24.3 \%$ and $12.7 \%$ of total above-ground $\mathrm{Zn}$ in wheat and barley, respectively (Coccina et al. 2019). In mycorrhizal maize, the plant physiological function such as photosynthesis in $\mathrm{Zn}$ deficient soils was improved with better nutrient uptake (Saboor et al. 2021).

In addition to providing plants with mycorrhizal $\mathrm{Zn}$ supply, fungi and bacteria may also regulated plant $\mathrm{Zn}$ transporters. Inoculation of barley with the AM fungus $R$. irregularis resulted in significant gene up-regulation of HvZIP13, a Zn transporter gene that is induced by low $\mathrm{Zn}$ availability, concomitant with improved grain and straw $\mathrm{Zn}$ concentrations (Watts-Williams and Cavagnaro 2018). Similarly, $R$. irregularis inoculation increased plant tolerance to soil $\mathrm{Zn}$ deficiency in M. truncatula; concomitantly, the fungus induced gene expression of MtZIP5 that is inducible by $\mathrm{Zn}$ deficiency (Nguyen et al. 2019). In rice plants inoculated with the Zn-mobilizing bacteria Enterobacter cloacae, gene expression of OsZIP1 and OsZIP5 was induced in the absence of $\mathrm{Zn}$ oxide as the insoluble $\mathrm{Zn}$ source in the growth medium, whereas expression of these two genes as well as OsZIP4 was repressed by the bacteria in the presence of $\mathrm{Zn}$ oxide (Krithika and Balachandar 2016). The microbial repression of these ZIP genes may reflect a feedback regulation by the microbe-dependent $\mathrm{Zn}$ sufficiency, which is similarly observed in the $R$. irregularis- 
inoculated barley and Medicago (Watts-Williams and Cavagnaro 2018, Nguyen et al. 2019).

Importantly, while AM fungi are capable of improving plant $\mathrm{Zn}$ nutrition under low soil $\mathrm{Zn}$ conditions, fungal protection of plants from excessive $\mathrm{Zn}$ accumulation at high $\mathrm{Zn}$ availability have also been documented in different plant species such as red clover (Trifolium pretense), Medicago, and tomato ( $\mathrm{Li}$ and Christie 2001, WattsWilliams et al. 2013, Nguyen et al. 2019). These dual plant-beneficial effects make AM fungi great choices as microbial tools for optimizing crop $\mathrm{Zn}$ acquisition.

\section{Molybdenum (Mo)}

Plants take in Mo in the form of molybdate $\left(\mathrm{MoO}_{4}{ }^{2-}\right)$. Apart from $\mathrm{Cu}, \mathrm{Mo}$ is the least abundant essential micronutrient found in most plant tissues (Kaiser et al. 2005). Mo deficiencies are considered as rare in most agricultural cropping areas, meanwhile its fertilization through foliar sprays can effectively supplement internal Mo and rescue the activity of Mo-dependent enzymes (Kaiser et al. 2005). Nonetheless, plant Mo acquisition can be improved by certain microbes. In sweet sorghum grown in an agricultural soil spiked with different concentrations of $\mathrm{MoS}_{2}$, AM fungal colonization by a Claroideoglomus etunicatum strain significantly enhanced plant Mo concentrations in both shoots and roots (Shi et al. 2020). In maize plants growing in soil supplemented with different levels of $\left(\mathrm{NH}_{4}\right)_{2} \mathrm{MoO}_{4}$, the same C. etunicatum strain also enhanced plant Mo concentrations in shoots and roots, with reductions in the shoot-to-root Mo ratio when Mo was supplemented at the levels considered as moderate and severe pollution (Shi et al. 2018).

\section{Nickel (Ni)}

$\mathrm{Ni}$ is required in higher plants only by the enzyme urease, while the mechanism of its assimilation by plants is largely elusive (Andresen et al. 2018). This micronutrient is generally available in fertilized soil in form of additives to fertilizers. For example, rock phosphate, which is a raw material for phosphatic fertilizers, is known to contain Ni ranging between 16.8 to $50.4 \mathrm{mg} \mathrm{kg}^{-1}$ (Chauhan et al. 2008). In fact, Ni has drawn much attention as a common heavy metal pollutant in soil, air, and water. Consequently, the research of microbes for improving plant $\mathrm{Ni}$ homeostasis has been focused on microbeinduced plant stress-alleviation, which is commonly mediated through reducing heavy metal uptake and/or increasing plant tolerance to the metal ion toxicity.

\section{Boron (B)}

Soil B exists in the form of the uncharged boric acid that can be readily taken up by plants (Miwa et al. 2009). Although B deficiency in many crops reportedly occur globally, it can be readily prevented and corrected by both soil and foliar applications (Shorrocks 1997). However, given that the range between B deficiency and toxicity to plants is very narrow (Matthes et al. 2020), beneficial microbes may be applied to improve B homeostasis in plants. For instance, soil supplementation of $25 \mu \mathrm{M}$ and $100 \mu \mathrm{M}$ B both increased plant photosynthesis efficiency under drought stress; however, the supplementation of $100 \mu \mathrm{M} \mathrm{B}$, but not $25 \mu \mathrm{M} \mathrm{B}$, caused a clear reduction in plant dry weight under well-watered condition (Quiroga et al. 2020). Inoculation with the AM fungus $R$. irregularis to these maize plants increased plant dry weight under both B-supplemented conditions compared to the non-mycorrhizal plants, irrespectively of the water availability. Although its mechanism remains unclear, this example demonstrates the ability of certain microbes in improving the efficacy of B supplementation for better plant growth.

\section{Nutrition-dependent plant-microbe association}

Under nutrient deficient conditions, the changes in plant metabolism may lead to changes in the root exudates and consequently affect the community of rootassociated microbes. A well-known example is $\mathrm{N}$ deficiency-induced production of flavonoids, which induce the species-specific rhizobial production of nodulation factors that in turn provoke deformation of the root hairs and nodule primordium formation (Relić et al. 1994, Coronado et al. 1995). Recent studies of different plant species also demonstrated root exudate-mediated re-assembly of rhizosphere microbiome in coping with plant nutrient deficiency. In maize under nitrogen deficient conditions, the plants not only up-regulated LRT1mediated lateral root development, which presumably enhanced root interactions with the bacteria family $O x a$ lobacteraceae that includes diazotrophic members, but also secreted flavones that increased the enrichment of Oxalobacteraceae in the rhizosphere, resulting in promoted plant $\mathrm{N}$ acquisition and growth (Yu et al. 2021). In Arabidopsis under Fe deficient conditions, the plants up-regulated gene expression of MYB72 that promotes root secretion of the antimicrobial coumarin scopoletin, leading to inhibition of the soil-borne fungal pathogens Fusarium oxysporum and Verticillium dahlia but not the beneficial rhizobacteria Pseudomonas simiae WCS417 and Pseudomonas capeferrum WCS358 (Stringlis et al. 2018), which are capable of enhancing plant iron acquisition (Zamioudis et al. 2015).

In contrast to the plant attraction of beneficial microbes for relieving nutrient deficiency, plant deterrence of the microbial association can occur under nutrient sufficient conditions (Fig. 2). This phenomenon can be seen in $\mathrm{N}$ fixation, which is inhibited by $\mathrm{N}$ fertilizers especially nitrate (Harper and Nicholas 1978). As shown in 
M. truncatula, this inhibition is mediated through MtCLE35, which is a CLAVATA3-like (CLE) signaling peptide that is transcriptionally up-regulated by local high $\mathrm{N}$ availability and that inhibits nodule formation (Moreau et al. 2021). Similarly, while mycorrhizal P uptake is a major benefit for plants colonized by AM fungi, sufficient $\mathrm{P}$ contents repress symbiotic gene expression and AM colonization in the roots of mycorrhizal petunia and tomato plants (Breuillin et al. 2010, Nagy et al. 2009). A thaliana plants allow the symbiosis with Colletotrichum tofieldiae, an endophytic fungus that can transfer phosphate to its host, only under $\mathrm{P}$ deficient conditions; whereas under $\mathrm{P}$ sufficient conditions, the plants deploy Trp-derived antifungal metabolites to deter the endophytic colonization of C. tofieldiae (Hiruma et al. 2016). The $P$ nutrition-dependent plant initiative was also observed in the association between Arabidopsis and the benefical rhizobacteria $B$. amyloliquefaciens GB03, albeit in an opposite manner compared to the association between Arabidopsis and C. tofieldiae. Under P sufficient conditions, the plants respond to the GB03-released volatile compound diacetyl with decreases in the microbeinduced ROS burst, thereby providing a permissive environment for the bacterial association; whereas under $\mathrm{P}$ deficient conditions, the plants respond to diacetyl with strong activation of salicylic acid (SA)- and jasmonic acid (JA)-mediated defense, thereby deterring the bacterial association (Morcillo et al. 2020). Thus Arabidopsis plants deploy different strategies in determining the association with fungi and bacteria. The different preferences on $\mathrm{P}$ availability probably reflect the different impacts by $C$. tofieldiae and GB03 on plant P acquisition, that is, the endophytic fungus can uptake and deliver $\mathrm{P}$ to the plant and is consequently welcomed by P-deficient plants, whereas the bacterium cannot deliver $\mathrm{P}$ to the plant and is consequently a competitor for $\mathrm{P}$ to $\mathrm{P}$-deficient plants. Therefore, the nutrient-dependent alterations in plantmicrobe interactions demonstrate the plant's initiative in determining the plant-microbe association for optimized benefits (Fig. 2).

Activation of the SA- or JA-mediated defense augments plant $\mathrm{P}$ starvation responses (PSR) (Morcillo et al., 2020). This makes it risky for plants to simply deter the bacteria $\mathrm{P}$ competitors under $\mathrm{P}$ deficient conditions, if the plant cannot alleviate its $\mathrm{P}$ deficiency stress by taking up more $\mathrm{P}$ or by taking advantage of bacteriareleased beneficial metabolites, which may be available in the rhizosphere without requiring bacteria colonization to the root. Indeed, when Arabidopsis plants were grown in P-depleted sterile medium with continuous exposure to diacetyl, the plants showed worsened PSR stress symptoms compared to their counterparts without exposure to diacetyl (Morcillo et al., 2020). Apparently, the binary interaction between the

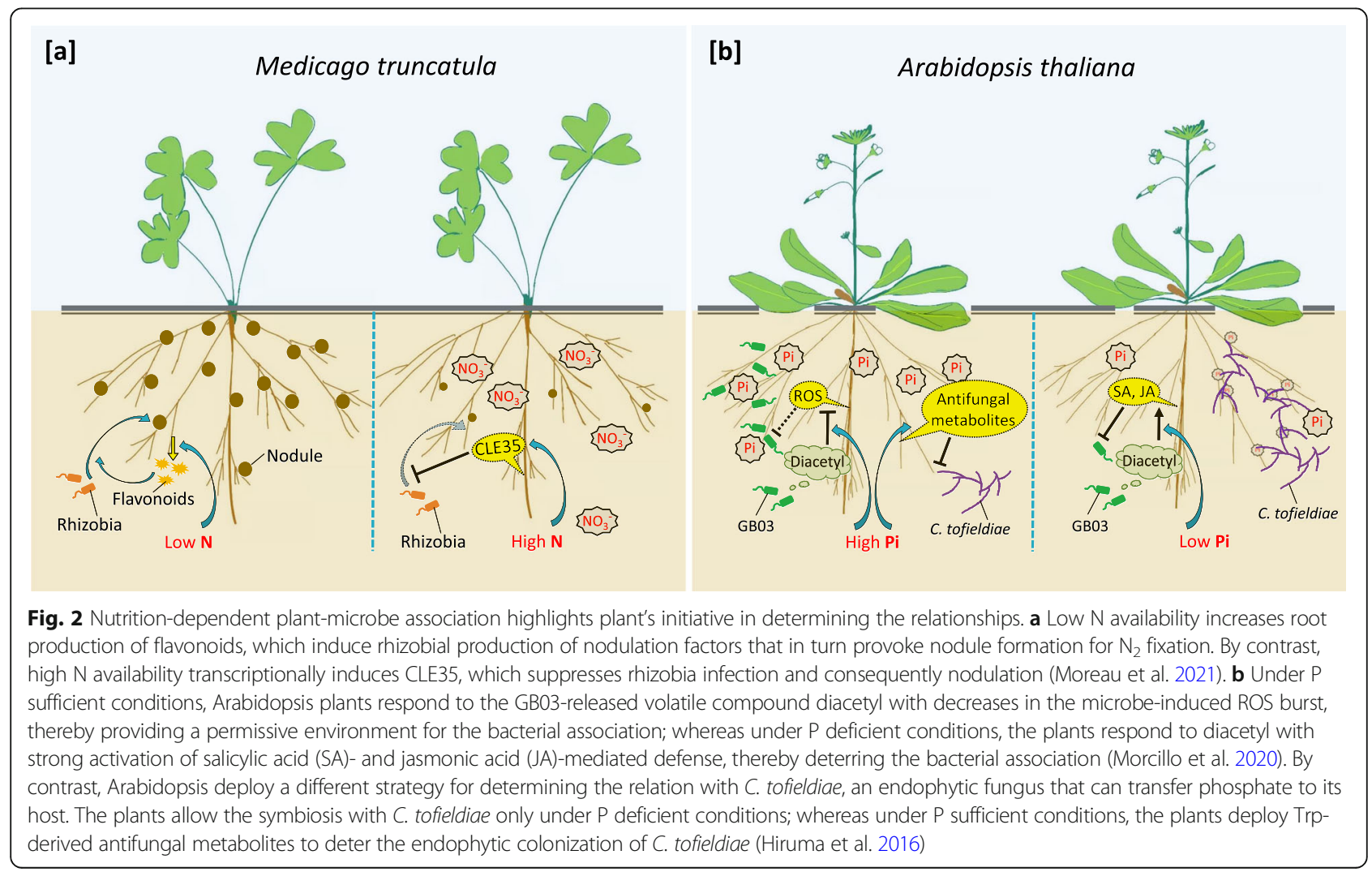


plant and the microbe is subject to the influence by many other biotic and abiotic factors. Plant interactions with individual microbes within the root microbiome are far more difficult to disentangle than in a binary system, because of the dynamic and interrelating correlations among the microbial community members and the plant. Consequently, nutrient-dependent changes in a particular microbiome member would likely reflect the outcome of a complex decision by the plant instead of a simple initiative based on the binary relation. For instance, soil-grown Arabidopsis with replete P supplementation showed increased abundance of Olpidium brassicae, a plant pathogen, in the root-associated fungal community (Fabiańska et al. 2019); meanwhile, mediumgrown Arabidopsis treated with a bacterial synthetic community showed P deficiency-induced enrichment of Burkholderia spp., which exacerbated plant P starvation possibly through behaving as competitors to the plant for P nutrition (Finkel et al. 2019). It appears that these presumably unwelcomed microbes dominated in the relationships under the examined conditions; alternatively, the observations may indicate compromises for unidentified benefits in the plants.

\section{Conclusions and perspectives}

A large number of microbes are capable of enhancing plant nutrition, mainly through increasing plant nutrient availability in soil and enhancing plant nutrient uptake (Fig. 1). Microbial regulation of plant genes for nutrient acquisition occurs, however, it remains largely unclear about what microbial factors induce the transcriptional regulation in the plant, and consequently about how the regulation is initiated at the molecular level. The beneficial microbes may also indirectly alleviate plant nutrient deficiency-stress, such as by increasing the activity of plant antioxidant enzymes to protect the plant from stress-induced ROS accumulation (Kabir et al. 2020). In addition, plant acquisition of some nutrients are inherently connected, indicating that beneficial microbes capable of enhancing plant acquisition of one nutrient may indirectly contribute to the acquisition of another nutrient. For instance, because $\mathrm{Mg}$ is important for rhizobial N2 fixation (Kiss et al. 2004), Mg supplementation to soybean plants improved the nodulation by Bradyrhizobium and the resultant $\mathrm{N}_{2}$ fixation under both $\mathrm{N}$ deficient and N-sufficient conditions (Khaitov 2018). Thus, interesting questions exist such as whether legume plant $\mathrm{N}$-acquisition can be enhanced by microbes that improve plant $\mathrm{Mg}$ acquisition, and whether legume plants would display a positive correlation between the activity of $\mathrm{N}_{2}$ fixation and the enrichment of $\mathrm{Mg}$ mobilizing microbes in the root microbiome.

Beneficial microbes are valuable resources for developing environment-friendly tools to meet the nutrient requirements of crops with or without chemical fertilization. In using the beneficial microbes, some potential complications may be relatively easy to be envisioned, such as that a microbe beneficial to one plant species may be ineffective or even pathogenic to another, and that AM fungi capable of providing heavy metal micronutrients may either supply excessive ions or function as a protective barrier when the particular metal nutrient is replete in the environment. Meanwhile, our current understanding of the microbe-enhanced plant nutrient acquisition is largely simplified, because most studies investigated binary plant-microbe systems and were oftentimes under in vitro or artificial conditions, which are quite different from the complex and dynamic environmental conditions that plants would encounter in nature. Such a gap would be improved by research efforts in disentangling the crosstalk among various biotic and abiotic factors, as well as the microbe-microbe interactions within the root microbiome.

\section{Abbreviations}

C: Carbon; H: hydrogen; O: oxygen; N: nitrogen; P: phosphorus; K: potassium; S: sulfur; Mg: magnesium; Ca: calcium; Fe: iron; Mn: manganese; Cu: copper; Zn: zinc; B: boron; Mo: molybdenum; Cl: chlorine; Ni: nickel; AM: arbuscular mycorrhizal; VOCs: volatile organic compounds

\section{Acknowledgements \\ The authors apologize to those colleagues whose work is not cited owing to} space constraints.

\section{Authors' contributions}

S.K.S researched and wrote a draft with inputs from X.W. and C.S. H.Z. researched and wrote the article. All authors reviewed and/or edited the article before submission. The authors read and approved the final manuscript.

\section{Funding}

Research in $\mathrm{H}$. Zhang lab is supported by the Chinese Academy of Sciences.

Availability of data and materials

Not applicable.

\section{Declarations}

Competing interests

The authors declare no competing interests.

\section{Author details}

${ }^{1}$ Shanghai Center for Plant Stress Biology, Center for Excellence in Molecular Plant Sciences, Chinese Academy of Sciences, Shanghai 201602, China.

University of Chinese Academy of Sciences, Beijing 100049, China.

Received: 11 November 2021 Accepted: 10 December 2021

Published online: 10 January 2022

\section{References}

Alewell C, Ringeval B, Ballabio C, Robinson DA, Panagos P, Borrelli P (2020) Global phosphorus shortage will be aggravated by soil erosion. Nat Commun 11(1): 4546. https://doi.org/10.1038/s41467-020-18326-7

Alori ET, Glick BR, Babalola OO (2017) Microbial phosphorus solubilization and its potential for use in sustainable agriculture. Front Microbiol 8(971):971. https://doi.org/10.3389/fmicb.2017.00971

Álvarez C, Navarro JA, Molina-Heredia FP, Mariscal V (2020) Endophytic colonization of rice (Oryza sativa L.) by the symbiotic strain Nostoc 
punctiforme PCC 73102. Mol Plant Microbe Interact 33(8):1040-1045. https:// doi.org/10.1094/MPMI-01-20-0015-SC

Andresen E, Peiter E, Kupper H (2018) Trace metal metabolism in plants. J Exp Bot 69(5):909-954. https://doi.org/10.1093/jxb/erx465

Andrews M, Andrews ME (2017) Specificity in legume-rhizobia symbioses. Int J Mol Sci 18(4):705. https://doi.org/10.3390/ijms18040705

Aziz M, Nadipalli RK, Xie X, Sun Y, Surowiec K, Zhang JL, Paré PW (2016) Augmenting sulfur metabolism and herbivore defense in arabidopsis by bacterial volatile signaling. Front Plant Sci 7(-):458. https://doi.org/10.3389/ fpls.2016.00458

Barberon M, Dubeaux G, Kolb C, Isono E, Zelazny E, Vert G (2014) Polarization of IRON-REGULATED TRANSPORTER 1 (IRT1) to the plant-soil interface plays crucial role in metal homeostasis. PNAS USA 111(22):8293-8298. https://doi. org/10.1073/pnas.1402262111

Baslam M, Garmendia I, Goicoechea N (2013) The arbuscular mycorrhizal symbiosis can overcome reductions in yield and nutritional quality in greenhouse-lettuces cultivated at inappropriate growing seasons. Sci Hortic 164:145-154. https://doi.org/10.1016/j.scienta.2013.09.021

Brady NC, Weil RR, Weil RR (2008) The nature and properties of soils. Prentice Hall Upper Saddle River, NJ

Breuillin F, Schramm J, Hajirezaei M, Ahkami A, Favre P, Druege U, Hause B, Bucher M, Kretzschmar T, Bossolini E, Kuhlemeier C, Martinoia E, Franken P, Scholz U, Reinhardt D (2010) Phosphate systemically inhibits development of arbuscular mycorrhiza in Petunia hybrida and represses genes involved in mycorrhizal functioning. Plant J 64(6):1002-1017. https://doi.org/10.1111/j.13 $65-313 \times .2010 .04385 . x$

Carrillo-Castañeda G, Muños JJ, Peralta-Videa J, Gomez E, Tiemannb K, DuarteGardea M et al (2002) Alfalfa growth promotion by bacteria grown under iron limiting conditions. Adv Environ Res 6(3):391-399. https://doi.org/10.101 6/S1093-0191(02)00054-0

Castulo-Rubio DY, Alejandre-Ramírez NA, Del Carmen O-MM, Santoyo G, MacíasRodríguez LI, Valencia-Cantero E (2015) Volatile organic compounds produced by the rhizobacterium Arthrobacter agilis UMCV2 modulate Sorghum bicolor (strategy II plant) morphogenesis and SbFRO1 transcription in vitro. J Plant Growth Regul 34(3):611-623. https://doi.org/10.1007/s00344015-9495-8

Chauhan S, Thakur R, Sharma G (2008) Nickel: its availability and reactions in soil. J Ind Pollut Control 24(1):1-8

Chen JG, Crooks RM, Seefeldt LC, Bren KL, Bullock RM, Darensbourg MY, Holland PL, Hoffman B, Janik MJ, Jones AK, Kanatzidis MG, King P, Lancaster KM, Lymar SV, Pfromm P, Schneider WF, Schrock RR (2018) Beyond fossil fueldriven nitrogen transformations. Science 360(6391):eaar6611. https://doi. org/10.1126/science.aar6611

Coccina A, Cavagnaro TR, Pellegrino E, Ercoli L, Mclaughlin MJ, Watts-Williams SJ (2019) The mycorrhizal pathway of zinc uptake contributes to zinc accumulation in barley and wheat grain. BMC Plant Biol 19(1):1-14. https:// doi.org/10.1186/s12870-019-1741-y

Coronado C, Zuanazzi JS, Sallaud C, Quirion J-C, Esnault R, Husson H-P, Kondorosi A, Ratet P (1995) Alfalfa root flavonoid production is nitrogen regulated. Plant Physiol 108(2):533-542. https://doi.org/10.1104/Pp.108.2.533

Curie C, Briat J-F (2003) Iron transport and signaling in plants. Annu Rev Plant Biol 54(1):183-206. https://doi.org/10.1146/annurev.arplant.54.031902.135018

Del Carmen O-MM, Macías-Rodríguez LI, Santoyo G, Farías-Rodríguez R, ValenciaCantero E (2013a) Medicago truncatula increases its iron-uptake mechanisms in response to volatile organic compounds produced by Sinorhizobium meliloti. Folia Microbiol (Praha) 58(6):579-585. https://doi.org/10.1007/s12223 013-0243-9

Del Carmen O-MM, Velázquez-Becerra C, Macías-Rodríguez LI, Santoyo G, FloresCortez I, Alfaro-Cuevas R et al (2013b) Arthrobacter agilis UMCV2 induces iron acquisition in Medicago truncatula (strategy I plant) in vitro via dimethylhexadecylamine emission. Plant Soil 362(1):51-66. https://doi.org/1 0.1007/s11104-012-1263-y

Dixon RA, Postgate JR (1971) Transfer of nitrogen-fixation genes by conjugation in Klebsiella pneumoniae. Nature 234(5323):47-48. https://doi.org/10.1038/234 $047 \mathrm{a} 0$

Eichhorn E, Van Der Ploeg JR, Leisinger T (1999) Characterization of a twocomponent alkanesulfonate monooxygenase from Escherichia coli. J Biol Chem 274(38):26639-26646. https://doi.org/10.1074/jbc.274.38.26639

Fabiańska I, Gerlach N, Almario J, Bucher M (2019) Plant-mediated effects of soil phosphorus on the root-associated fungal microbiota in Arabidopsis thaliana. New Phytol 221(4):2123-2137. https://doi.org/10.1111/nph.15538
Farag MA, Ryu C-M, Sumner LW, Paré PW (2006) GC-MS SPME profiling of rhizobacterial volatiles reveals prospective inducers of growth promotion and induced systemic resistance in plants. Phytochemistry 67(20):2262-2268. https://doi.org/10.1016/j.phytochem.2006.07.021

Farag MA, Zhang H, Ryu C-M (2013) Dynamic chemical communication between plants and bacteria through airborne signals: induced resistance by bacterial volatiles. J Chem Ecol 39(7):1007-1018. https://doi.org/10.1007/s10886-0130317-9

Ferrol N, Tamayo E, Vargas P (2016) The heavy metal paradox in arbuscular mycorrhizas: from mechanisms to biotechnological applications. J Exp Bot 67(22):erw403. https://doi.org/10.1093/jxb/erw403

Finkel OM, Salas-González I, Castrillo G, Spaepen S, Law TF, Teixeira PJPL, Jones CD, Dangl JL (2019) The effects of soil phosphorus content on plant microbiota are driven by the plant phosphate starvation response. PLoS Biol 17(11):e3000534. https://doi.org/10.1371/journal.pbio.3000534

Freitas MA, Medeiros FH, Carvalho SP, Guilherme LR, Teixeira WD, Zhang H, Paré PW (2015) Augmenting iron accumulation in cassava by the beneficial soil bacterium Bacillus subtilis (GBO3). Front. Plant Sci 6:596. https://doi.org/10.33 89/fpls.2015.00596

Gahan J, Schmalenberger A (2015) Arbuscular mycorrhizal hyphae in grassland select for a diverse and abundant hyphospheric bacterial community involved in sulfonate desulfurization. Appl. Soil Ecol 89:113-121. https://doi. org/10.1016/j.apsoil.2014.12.008

Ghosh S, Bal B, Das A (2018) Enhancing manganese recovery from low-grade ores by using mixed culture of indigenously isolated bacterial strains. Geomicrobiol J 35(3):242-246. https://doi.org/10.1080/01490451.2017.1362080

Giovannetti M, Tolosano M, Volpe V, Kopriva S, Bonfante P (2014) Identification and functional characterization of a sulfate transporter induced by both sulfur starvation and mycorrhiza formation in Lotus japonicus. New Phytol 204(3):609-619. https://doi.org/10.1111/nph.12949

Gong Z, Xiong L, Shi H, Yang S, Herrera-Estrella LR, Xu G, Chao DY, Li J, Wang PY, Qin F, Li J, Ding Y, Shi Y, Wang Y, Yang Y, Guo Y, Zhu JK (2020) Plant abiotic stress response and nutrient use efficiency. Sci China Life Sci 63(5):635-674. https://doi.org/10.1007/s11427-020-1683-x

Govindarajulu M, Pfeffer PE, Jin H, Abubaker J, Douds DD, Allen JW, Bücking H, Lammers PJ, Shachar-Hill Y (2005) Nitrogen transfer in the arbuscular mycorrhizal symbiosis. Nature 435(7043):819-823. https://doi.org/10.1038/na ture03610

Guerinot ML, Meidl EJ, Plessner O (1990) Citrate as a siderophore in Bradyrhizobium japonicum. J Bacteriol 172(6):3298-3303. https://doi.org/1 0.1128/jb.172.6.3298-3303.1990

Guerrero-Galán C, Garcia K, Houdinet G, Zimmermann S-D (2018) Hc TOK1 participates in the maintenance of $\mathrm{K}+$ homeostasis in the ectomycorrhizal fungus Hebeloma cylindrosporum, which is essential for the symbiotic K+ nutrition of Pinus pinaster. Plant Signal Behav 13(6):e1480845

Harper JE, Nicholas JC (1978) Nitrogen metabolism of soybeans: I. effect of tungstate on nitrate utilization, nodulation, and growth. Plant Physiol 62(4): 662-664. https://doi.org/10.1104/pp.62.4.662

Harrison MJ, Dewbre GR, Liu J (2002) A phosphate transporter from Medicago truncatula involved in the acquisition of phosphate released by arbuscular mycorrhizal fungi. Plant Cell 14(10):2413-2429. https://doi.org/10.1105/tpc. 004861

Hermans C, Vuylsteke M, Coppens F, Cristescu SM, Harren FJ, Inzé D et al (2010) Systems analysis of the responses to long-term magnesium deficiency and restoration in Arabidopsis thaliana. New Phytol 187(1):132-144. https://doi. org/10.1111/j.1469-8137.2010.03257.x

Hernández-Calderón E, Aviles-Garcia ME, Castulo-Rubio DY, Macías-Rodríguez L, Ramírez VM, Santoyo G, López-Bucio J, Valencia-Cantero E (2018) Volatile compounds from beneficial or pathogenic bacteria differentially regulate root exudation, transcription of iron transporters, and defense signaling pathways in Sorghum bicolor. Plant Mol Biol 96(3):291-304. https://doi.org/1 0.1007/s11103-017-0694-5

Hiruma K, Gerlach N, Sacristán S, Nakano RT, Hacquard S, Kracher B, Neumann U, Ramírez D, Bucher M, O'Connell RJ, Schulze-Lefert P (2016) Root endophyte Colletotrichum tofieldiae confers plant fitness benefits that are phosphate status dependent. Cell 165(2):464-474. https://doi.org/10.1016/j.cell.2016.02.028

Jarstfer A, Farmer-Koppenol P, Sylvia DM (1998) Tissue magnesium and calcium affect arbuscular mycorrhiza development and fungal reproduction. Mycorrhiza 7(5):237-242. https://doi.org/10.1007/s005720050186

Jiang F, Zhang L, Zhou J, George TS, Feng G (2021) Arbuscular mycorrhizal fungi enhance mineralisation of organic phosphorus by carrying bacteria along 
their extraradical hyphae. New Phytol 230(1):304-315. https://doi.org/1 0.1111/nph.17081

Jing X, Cui Q, Li X, Yin J, Ravichandran V, Pan D, Fu J, Tu Q, Wang H, Bian X, Zhang $Y$ (2020) Engineering Pseudomonas protegens Pf-5 to improve its antifungal activity and nitrogen fixation. Microb Biotechnol 13(1):118-133. https://doi.org/10.1111/1751-7915.13335

Kabir AH, Debnath T, Das U, Prity SA, Haque A, Rahman MM et al (2020) Arbuscular mycorrhizal fungi alleviate Fe-deficiency symptoms in sunflower by increasing iron uptake and its availability along with antioxidant defense. Plant Physiol. Biochem 150:254-262. https:/doi.org/10.1016/.jplaphy.2020.03.010

Kaiser BN, Gridley KL, Ngaire Brady J, Phillips T, Tyerman SD (2005) The role of molybdenum in agricultural plant production. Ann Bot 96(5):745-754. https://doi.org/10.1093/aob/mci226

Kamran S, Shahid I, Baig DN, Rizwan M, Malik KA, Mehnaz S (2017) Contribution of zinc solubilizing bacteria in growth promotion and zinc content of wheat. Front. Microbiol 8:2593. https://doi.org/10.3389/fmicb.2017.02593

Kanchiswamy CN, Malnoy M, Maffei ME (2015) Chemical diversity of microbial volatiles and their potential for plant growth and productivity. Front. Plant Sci 6:151 Artn 151

Kertesz MA (2000) Riding the sulfur cycle-metabolism of sulfonates and sulfate esters in gram-negative bacteria. FEMS Microbiol. Rev 24(2):135-175. https:// doi.org/10.1016/S0168-6445(99)00033-9

Kertesz MA, Fellows E, Schmalenberger A (2007) Rhizobacteria and plant sulfur supply. Adv Appl Microbiol 62:235-268. https://doi.org/10.1016/50065-2164 (07)62008-5

Kertesz MA, Mirleau P (2004) The role of soil microbes in plant Sulphur nutrition. J Exp Bot 55(404):1939-1945. https://doi.org/10.1093/jxb/erh176

Khaitov B (2018) Effects of Rhizobium inoculation and magnesium application on growth and nodulation of soybean (Glycine max L.). J Plant Nutr 41(16): 2057-2068. https://doi.org/10.1080/01904167.2018.1485164

King J, Quinn J (1997) The utilization of organosulphonates by soil and freshwater bacteria. Lett Appl Microbiol 24(6):474-478. https://doi.org/10.104 6/j.1472-765X.1997.00062.x

Kiss SA, Stefanovits-Bányai E, Takács-Hájos M (2004) Magnesium-content of rhizobium nodules in different plants: the importance of magnesium in nitrogen-fixation of nodules. J Am Coll Nutr 23(6):751S-753S. https://doi. org/10.1080/07315724.2004.10719422

Kloepper JW, Leong J, Teintze M, Schroth MN (1980) Enhanced plant growth by siderophores produced by plant growth-promoting rhizobacteria. Nature 286(5776):885-886. https://doi.org/10.1038/286885a0

Kong W-L, Wang Y-H, Wu X-Q (2021) Enhanced iron uptake in plants by volatile emissions of Rahnella aquatilis JZ-GX1. Front Plant Sci 12:704000. https://doi. org/10.3389/fpls.2021.704000

Kothari S, Marschner H, Römheld V (1991) Effect of a vesicular-arbuscular mycorrhizal fungus and rhizosphere micro-organisms on manganese reduction in the rhizosphere and manganese concentrations in maize (Zea mays L.). New Phytol 117(4):649-655. https://doi.org/10.1111/j.1469-8137.1 991.tb00969.x

Krithika S, Balachandar D (2016) Expression of zinc transporter genes in rice as influenced by zinc-solubilizing Enterobacter cloacae strain ZSB14. Front. Plant Sci 7:446. https://doi.org/10.3389/Fpls.2016.00446

Lee Y-J, George E (2005) Contribution of mycorrhizal hyphae to the uptake of metal cations by cucumber plants at two levels of phosphorus supply. Plant Soil 278(1):361-370. https://doi.org/10.1007/s11104-005-0373-1

Lehnert N, Dong HT, Harland JB, Hunt AP, White CJ (2018) Reversing nitrogen fixation. Nat Rev Chem 2(10):278-289. https://doi.org/10.1038/s41570-0180041-7

Li X, Christie P (2001) Changes in soil solution Zn and pH and uptake of Zn by arbuscular mycorrhizal red clover in Zn-contaminated soil. Chemosphere 42(2):201-207. https://doi.org/10.1016/s0045-6535(00)00126-0

Li X, Yin Y, Fan S, Xu X, Amombo E, Xie Y, Fu J (2021) Aspergillus aculeatus enhances potassium uptake and photosynthetic characteristics in perennial ryegrass by increasing potassium availability. J Appl Microbiol. https://doi. org/10.1111/jam.15186

Li X-L, Marschner H, George E (1991) Acquisition of phosphorus and copper by VA-mycorrhizal hyphae and root-to-shoot transport in white clover. Plant Soil 136(1):49-57. https://doi.org/10.1007/Bf02465219

Lim BL, Yeung P, Cheng C, Hill JE (2007) Distribution and diversity of phytatemineralizing bacteria. ISME J 1(4):321-330. https://doi.org/10.1038/ismej.2 007.40
Liu X-M, Zhang H (2015) The effects of bacterial volatile emissions on plant abiotic stress tolerance. Front. Plant Sci 6:774. https://doi.org/10.3389/fpls.201 5.00774

Lugtenberg B, Kamilova F (2009) Plant-growth-promoting rhizobacteria. Annu Rev. Microbiol 63:541-556. https://doi.org/10.1146/annurev.micro.62.081307.1 62918

Marastoni L, Pii Y, Maver M, Valentinuzzi F, Cesco S, Mimmo T (2019) Role of Azospirillum brasilense in triggering different Fe chelate reductase enzymes in cucumber plants subjected to both nutrient deficiency and toxicity. Plant Physiol. Biochem 136:118-126. https://doi.org/10.1016/j.plaphy.2019.01.013

Martínez-Medina A, Van Wees SC, Pieterse CM (2017) Airborne signals from Trichoderma fungi stimulate iron uptake responses in roots resulting in priming of jasmonic acid-dependent defences in shoots of Arabidopsis thaliana and Solanum lycopersicum. Plant Cell Environ 40(11):2691-2705. https://doi.org/10.1111/pce.13016

Masood S, Bano A (2016) Mechanism of potassium solubilization in the agricultural soils by the help of soil microorganisms. In Potassium solubilizing microorganisms for sustainable agriculture. Springer, pp 137-147. https://doi. org/10.1007/978-81-322-2776-2_10

Matthes MS, Robil JM, Mcsteen P (2020) From element to development: the power of the essential micronutrient boron to shape morphological processes in plants. J Exp Bot 71(5):1681-1693. https://doi.org/10.1093/jxb/ eraa042

Meena V, Maurya B, Bahadur I (2014) Potassium solubilization by bacterial strain in waste mica. Bangladesh J Bot 43(2):235-237. https://doi.org/10.3329/bjb. v43i2.21680

Meldau DG, Meldau S, Hoang LH, Underberg S, Wünsche H, Baldwin IT (2013) Dimethyl disulfide produced by the naturally associated bacterium Bacillus $s p$ B55 promotes Nicotiana attenuata growth by enhancing sulfur nutrition. Plant Cell 25(7):2731-2747. https://doi.org/10.1105/tpc.113.114744

Mitchell DB, Vogel K, Weimann BJ, Pasamontes L, Van Loon AP (1997) The phytase subfamily of histidine acid phosphatases: isolation of genes for two novel phytases from the fungi aspergillus terreus and Myceliophthora thermophila. Microbiology 143(1):245-252. https://doi.org/10.1099/002212 87-143-1-245

Miwa K, Kamiya T, Fujiwara T (2009) Homeostasis of the structurally important micronutrients. B and Si Curr Opin Plant Biol 12(3):307-311. https://doi.org/1 0.1016/j.pbi.2009.04.007

Mohanty S, Ghosh S, Nayak S, Das A (2017) Isolation, identification and screening of manganese solubilizing fungi from low-grade manganese ore deposits. Geomicrobiol J 34(4):309-316. https://doi.org/10.1080/014 90451.2016.1189016

Montejano-Ramírez V, García-Pineda E, Valencia-Cantero E (2020) Bacterial compound $\mathrm{N}, \mathrm{N}$-dimethylhexadecylamine modulates expression of iron deficiency and defense response genes in Medicago truncatula independently of the jasmonic acid pathway. Plants 9(5):624. https://doi. org/10.3390/plants9050624

Morcillo RJ, Singh SK, He D, An G, Vilchez Il, Tang K, Yuan F, Sun Y, Shao C, Zhang S, Yang Y, Liu X, Dang Y, Wang W, Gao J, Huang W, Lei M, Song CP, Zhu JK, Macho AP, Paré PW, Zhang H (2020) Rhizobacterium-derived diacetyl modulates plant immunity in a phosphate-dependent manner. EMBO J 39(2): e102602. https://doi.org/10.15252/embj.2019102602

Morcillo RJL, Manzanera M (2021) The effects of plant-associated bacterial exopolysaccharides on plant abiotic stress tolerance. Metabolites 11(6):337. https://doi.org/10.3390/metabo11060337

Moreau C, Gautrat P, Frugier F (2021) Nitrate-induced CLE35 signaling peptides inhibit nodulation through the SUNN receptor and miR2111 repression. Plant Physiol 185(3):1216-1228. https://doi.org/10.1093/plphys/kiaa094

Mus F, Crook MB, Garcia K, Garcia Costas A, Geddes BA, Kouri ED, Paramasivan P, Ryu MH, Oldroyd GED, Poole PS, Udvardi MK, Voigt CA, Ané JM, Peters JW (2016) Symbiotic nitrogen fixation and the challenges to its extension to nonlegumes. Appl Environ Microbiol 82(13):3698-3710. https://doi.org/10.112 8/AEM.01055-16

Nagy R, Drissner D, Amrhein N, Jakobsen I, Bucher M (2009) Mycorrhizal phosphate uptake pathway in tomato is phosphorus-repressible and transcriptionally regulated. New Phytol 181(4):950-959. https://doi.org/1 $0.1111 / j .1469-8137.2008 .02721 . x$

Nagy R, Karandashov V, Chague V, Kalinkevich K, Tamasloukht MB, Xu G et al (2005) The characterization of novel mycorrhiza-specific phosphate transporters from Lycopersicon esculentum and Solanum tuberosum uncovers functional redundancy in symbiotic phosphate transport in 
solanaceous species. Plant J 42(2):236-250. https://doi.org/10.1111/j.13 65-313X.2005.02364.X

Nannipieri P, Giagnoni L, Landi L, Renella G (2011) In: Bunemann EK, Oberson A, Frossard $\mathrm{E}$ (eds) Role of phosphatase enzymes in soil. In 'phosphorus in action'. Springer, Berlin, Heidelberg, pp 215-243

Nguyen TD, Cavagnaro TR, Watts-Williams SJ (2019) The effects of soil phosphorus and zinc availability on plant responses to mycorrhizal fungi: a physiological and molecular assessment. Sci Rep 9(1):1-13. https://doi.org/1 0.1038/s41598-019-51369-5

Nogueira MA, Cardoso EJBN (2003) Mycorrhizal effectiveness and manganese toxicity in soybean as affected by soil type and endophyte. Sci Agric 60:329335. https://doi.org/10.1590/S0103-90162003000200018

Paszkowski U, Kroken S, Roux C, Briggs SP (2002) Rice phosphate transporters include an evolutionarily divergent gene specifically activated in arbuscular mycorrhizal symbiosis. PNAS USA 99(20):13324-13329. https://doi.org/10.1 073/pnas.202474599

Peng L, Shan X, Yang Y, Wang Y, Druzhinina IS, Pan X, Jin W, He X, Wang X, Zhang X, Martin FM, Yuan Z (2021) Facultative symbiosis with a saprotrophic soil fungus promotes potassium uptake in American sweetgum trees. Plant Cell Environ 44(8):2793-2809. https://doi.org/10.1111/pce.14053

Perner H, Schwarz D, Bruns C, Mäder P, George E (2007) Effect of arbuscular mycorrhizal colonization and two levels of compost supply on nutrient uptake and flowering of pelargonium plants. Mycorrhiza 17(5):469-474. https://doi.org/10.1007/s00572-007-0116-7

Prasad D, Verma N, Bakshi M, Narayan OP, Singh AK, Dua M, Johri AK (2019) Functional characterization of a magnesium transporter of root endophytic fungus Piriformospora indica. Front Microbiol 9:3231. https://doi.org/10.3389/ fmicb.2018.03231

Prity SA, Sajib SA, Das U, Rahman MM, Haider SA, Kabir AH (2020) Arbuscular mycorrhizal fungi mitigate Fe deficiency symptoms in sorghum through phytosiderophore-mediated Fe mobilization and restoration of redox status. Protoplasma 257(5):1373-1385. https://doi.org/10.1007/s00709-020-01517-w

Quiroga G, Erice G, Aroca R, Ruiz-Lozano JM (2020) Elucidating the possible involvement of maize aquaporins in the plant boron transport and homeostasis mediated by Rhizophagus irregularis under drought stress conditions. Int J Mol Sci 21(5):1748. https://doi.org/10.3390/ijms21051748

Rajkumar M, Ae N, Prasad MNV, Freitas H (2010) Potential of siderophoreproducing bacteria for improving heavy metal phytoextraction. Trends Biotechnol 28(3):142-149. https://doi.org/10.1016/j.tibtech.2009.12.002

Rausch C, Daram P, Brunner S, Jansa J, Laloi M, Leggewie G, Amrhein N, Bucher M (2001) A phosphate transporter expressed in arbuscule-containing cells in potato. Nature 414(6862):462-465. https://doi.org/10.1038/35106601

Relić B, Perret X, Estrada-García MT, Kopcinska J, Golinowski W, Krishnan H et al (1994) Nod factors of Rhizobium are a key to the legume door. Mol Microbiol 13(1):171-179. https://doi.org/10.1111/j.1365-2958.1994.tb00412.x

Riaz N, Guerinot ML (2021) All together now: regulation of the iron deficiency response. J Exp Bot 72(6):2045-2055. https://doi.org/10.1093/jxb/erab003

Richardson AE, Simpson RJ (2011) Soil microorganisms mediating phosphorus availability update on microbial phosphorus. Plant Physiol 156(3):989-996. https://doi.org/10.1104/pp.111.175448

RodríGuez H, Fraga R (1999) Phosphate solubilizing bacteria and their role in plant growth promotion. Biotechnol Adv 17(4-5):319-339. https://doi.org/1 0.1016/s0734-9750(99)00014-2

Roy S, Liu W, Nandety RS, Crook A, Mysore KS, Pislariu Cl, Frugoli J, Dickstein R, Udvardi MK (2020) Celebrating 20 years of genetic discoveries in legume nodulation and symbiotic nitrogen fixation. Plant Cell 32(1):15-41. https://doi. org/10.1105/tpc. 19.00279

Saboor A, Ali MA, Danish S, Ahmed N, Fahad S, Datta R, Ansari MJ, Nasif O, Rahman MH, Glick BR (2021) Effect of arbuscular mycorrhizal fungi on the physiological functioning of maize under zinc-deficient soils. Sci Rep 11(1):111. https://doi.org/10.1038/s41598-021-97742-1

Saia S, Rappa V, Ruisi P, Abenavoli MR, Sunseri F, Giambalvo D, Frenda AS, Martinelli $F$ (2015) Soil inoculation with symbiotic microorganisms promotes plant growth and nutrient transporter genes expression in durum wheat. Front. Plant Sci 6:815. https://doi.org/10.3389/fpls.2015.00815

Sanket A, Ghosh S, Sahoo R, Nayak S, Das A (2017) Molecular identification of acidophilic manganese (Mn)-solubilizing bacteria from mining effluents and their application in mineral beneficiation. Geomicrobiol J 34(1):71-80. https:// doi.org/10.1080/01490451.2016.1141340

Santos K, Moure V, Hauer V, Santos AS, Donatti L, Galvão C et al (2017) Wheat colonization by an Azospirillum brasilense ammonium-excreting strain reveals upregulation of nitrogenase and superior plant growth promotion. Plant Soil 415(1):245-255. https://doi.org/10.1007/s11104-016-3140-6

Sharma SB, Sayyed RZ, Trivedi MH, Gobi TA (2013) Phosphate solubilizing microbes: sustainable approach for managing phosphorus deficiency in agricultural soils. SpringerPlus 2(1):1-14. https://doi.org/10.1186/2193-1801-2-587

Shi Z, Zhang J, Lu S, Li Y, Wang F (2020) Arbuscular mycorrhizal fungi improve the performance of sweet sorghum grown in a Mo-contaminated soil. J Fungi 6(2):44. https://doi.org/10.3390/jof6020044

Shi Z, Zhang J, Wang F, Li K, Yuan W, Liu J (2018) Arbuscular mycorrhizal inoculation increases molybdenum accumulation but decreases molybdenum toxicity in maize plants grown in polluted soil. RSC Adv 8(65): 37069-37076. https://doi.org/10.1039/c8ra07725h

Shorrocks VM (1997) The occurrence and correction of boron deficiency. Plant Soil 193(1):121-148. https://doi.org/10.1023/A:1004216126069

Smil V (2000) Phosphorus in the environment: natural flows and human interferences. Annu Rev Energ Environ 25(1):53-88. https://doi.org/10.1146/a nnurev.energy.25.1.53

Smith MJ, Shoolery J, Schwyn B, Holden I, Neilands J (1985) Rhizobactin, a structurally novel siderophore from Rhizobium meliloti. J Am Chem Soc 107(6):1739-1743. https://doi.org/10.1021/Ja00292a047

Stringlis IA, Yu K, Feussner K, De Jonge R, Van Bentum S, Van Verk MC et al (2018) MYB72-dependent coumarin exudation shapes root microbiome assembly to promote plant health. PNAS USA 115(22):E5213-E5E22. https:// doi.org/10.1073/pnas.1722335115

Svistoonoff S, Hocher V, Gherbi H (2014) Actinorhizal root nodule symbioses: what is signalling telling on the origins of nodulation. Curr Opin Plant Biol 20:11-18. https://doi.org/10.1016/j.pbi.2014.03.001

Takahashi H, Kopriva S, Giordano M, Saito K, Hell R (2011) Sulfur assimilation in photosynthetic organisms: molecular functions and regulations of transporters and assimilatory enzymes. Annu Rev Plant Biol 62:157-184. https://doi.org/10.1146/annurev-arplant-042110-103921

Vaid SK, Kumar B, Sharma A, Shukla A, Srivastava P (2014) Effect of Zn solubilizing bacteria on growth promotion and Zn nutrition of rice. J Soil Sci Plant Nutr 14(4):889-910. https://doi.org/10.4067/S0718-95162014005000071

Van Velzen R, Holmer R, Bu F, Rutten L, Van Zeijl A, Liu W et al (2018) Comparative genomics of the nonlegume Parasponia reveals insights into evolution of nitrogen-fixing rhizobium symbioses. PNAS USA 115(20):E4700E47E9. https://doi.org/10.1073/pnas.1721395115

Vermeij P, Wietek C, Kahnert A, Wuèest T, Kertesz MA (1999) Genetic organization of Sulphur-controlled aryl desulphonation in Pseudomonas putida S-313. Mol Microbiol 32(5):913-926. https://doi.org/10.1046/j.1365-2958.1999.01398.x

Vilchez JI, Yang Y, He D, Zi H, Peng L, Lv S, Kaushal R, Wang W, Huang W, Liu R, Lang Z, Miki D, Tang K, Paré PW, Song CP, Zhu JK, Zhang H (2020) DNA demethylases are required for myo-inositol-mediated mutualism between plants and beneficial rhizobacteria. Nat Plants 6(8):983-995. https://doi.org/1 0.1038/s41477-020-0707-2

Wang S, Chen A, Xie K, Yang X, Luo Z, Chen J, Zeng D, Ren Y, Yang C, Wang L, Feng H, López-Arredondo DL, Herrera-Estrella LR, Xu G (2020) Functional analysis of the OsNPF4. 5 nitrate transporter reveals a conserved mycorrhizal pathway of nitrogen acquisition in plants. PNAS USA 117(28):16649-16659. https://doi.org/10.1073/pnas.2000926117

Watts-Williams SJ, Cavagnaro TR (2018) Arbuscular mycorrhizal fungi increase grain zinc concentration and modify the expression of root ZIP transporter genes in a modern barley (Hordeum vulgare) cultivar. Plant Sci 274:163-170. https://doi.org/10.1016/j.plantsci.2018.05.015

Watts-Williams SJ, Patti AF, Cavagnaro TR (2013) Arbuscular mycorrhizas are beneficial under both deficient and toxic soil zinc conditions. Plant Soil 371(1):299-312. https://doi.org/10.1007/s11104-013-1670-8

Weisskopf L, Schulz S, Garbeva P (2021) Microbial volatile organic compounds in intra-kingdom and inter-kingdom interactions. Nat Rev Microbiol 19(6):391404. https://doi.org/10.1038/s41579-020-00508-1

Whitelaw M, Harden T, Helyar K (1999) Phosphate solubilisation in solution culture by the soil fungus Penicillium radicum. Soil Biol Biochem 31(5):655665. https://doi.org/10.1016/S0038-0717(98)00130-8

Xu G-H, Chague V, Melamed-Bessudo C, Kapulnik Y, Jain A, Raghothama KG, Levy AA, Silber A (2007) Functional characterization of LePT4: a phosphate transporter in tomato with mycorrhiza-enhanced expression. J Exp Bot 58(10):2491-2501. https://doi.org/10.1093/jxb/erm096

Yu P, He X, Baer M, Beirinckx S, Tian T, Moya YA et al (2021) Plant flavones enrich rhizosphere Oxalobacteraceae to improve maize performance under 
nitrogen deprivation. Nat Plants 7(4):481-499. https://doi.org/10.1038/s41477021-00897-y

Zamioudis C, Korteland J, Van Pelt JA, Van Hamersveld M, Dombrowski N, Bai Y et al (2015) Rhizobacterial volatiles and photosynthesis-related signals coordinate MYB 72 expression in Arabidopsis roots during onset of induced systemic resistance and iron-deficiency responses. Plant J 84(2):309-322. https://doi.org/10.1111/tpj.12995

Zhang F, Du P, Song C-X, Wu Q-S (2015) Alleviation of mycorrhiza to magnesium deficiency in trifoliate orange: changes in physiological activity. Emir J Food Agric 27:763-769

Zhang H, Sun Y, Xie X, Kim MS, Dowd SE, Paré PW (2009) A soil bacterium regulates plant acquisition of iron via deficiency-inducible mechanisms. Plant J 58(4):568-577. https://doi.org/10.1111/j.1365-313X.2009.03803.x

Zhang H, Xie X, Kim MS, Kornyeyev DA, Holaday S, Paré PW (2008) Soil bacteria augment Arabidopsis photosynthesis by decreasing glucose sensing and abscisic acid levels in planta. Plant J 56(2):264-273. https://doi.org/10.1111/ j.1365-313X.2008.03593.X

Zhao F, Lehmann J, Solomon D, Fox M, Mcgrath S (2006) Sulphur speciation and turnover in soils: evidence from Sulphur K-edge XANES spectroscopy and isotope dilution studies. Soil Biol Biochem 38(5):1000-1007. https://doi.org/1 0.1016/j.soilbio.2005.08.013

Zhou C, Guo J, Zhu L, Xiao X, Xie Y, Zhu J et al (2016) Paenibacillus polymyxa BFKC01 enhances plant iron absorption via improved root systems and activated iron acquisition mechanisms. Plant Physiol Biochem 105:162-173. https://doi.org/10.1016/.jplaphy.2016.04.025

\section{Publisher's Note}

Springer Nature remains neutral with regard to jurisdictional claims in published maps and institutional affiliations. 